\title{
VAMPIRE BAT Desmodus rotundus SHELTERS IN THE CENTRAL REGION OF SÃO PAULO STATE, BRAZIL
}

\author{
Paulo Jacques Mialhe ${ }^{1}$ \\ Luiz Eduardo Moschini ${ }^{2}$ \\ Diego Peruchi Trevisan ${ }^{2}$
}

\begin{abstract}
The vampire bat Desmodus rotundus is the main transmitter of domestic herbivorous rabies, which causes economic losses in cattle raising, being a serious public health problem. The use of Geographic Information Systems (GIS) allows the spatial monitoring of these bats' shelters, which is an efficient way to prevent and control rabies. This study located shelters of $D$. rotundus in the Eastern Center region of São Paulo state and identified the types of shelters used (natural or artificial), their proximity to water, sexual composition, and a population estimated of the colonies. Searches were carried out by colonies of vampire bats in natural and artificial shelters from 2002 to 2004, covering 18 municipalities. After being located, the shelters were georeferenced, being recorded the nature of the shelter (natural or artificial), use (shelters of males, maternities, digestive), and estimated population. The data were incorporated into a GIS, producing a thematic map of the shelter's location and its distance from the local water bodies. There were found $1.567 \mathrm{D}$. rotundus distributed in 94 shelters, where only six shelters $(6.38 \%)$ were natural (caves). Most shelters $(79.78 \%)$ were sparsely populated, with up to 15 bats, including male shelters (46 shelters) and 30 maternities (63.82\% of maternities). Five shelters $(5.37 \%)$ had between 50 and 100 bats and only two shelters $(2.15 \%)$ had a population greater than 100 bats. Six shelters $(6.38 \%)$ were inhabited houses, which is a concern for public health, as these may constitute a source of dangerous contamination for domestic and human carnivores. All the shelters were at a distance of up to $2 \mathrm{~km}$ of rivers or streams. The high percentage of artificial shelters found is a consequence of the intensification of the anthropic changes that increase the supply of food and shelter to $D$. rotundus, which is associated with a large drainage network that favors the dispersion of this species of bat in the region. The proximity of all D. rotundus shelters to the drainage network corroborates other studies in São Paulo state, where the areas close to the main rivers generally favor the existence of a larger number of shelters.
\end{abstract}

Keywords: Vampire bat, bat shelter, GIS.

\section{ABRIGOS DO MORCEGO HEMATÓFAGO DESMODUS ROTUNDUS NA REGIÃO CENTRAL DO ESTADO DE SÃO PAULO, BRASIL}

\section{RESUMO}

O morcego hematófago Desmodus rotundus é o principal transmissor da raiva dos herbívoros domésticos, o qual causa prejuízos econômicos na pecuária, além de ser um sério problema de saúde pública. $\mathrm{O}$ uso de Sistemas de Informações Geográficas (SIG) permite o monitoramento espacial dos abrigos destes morcegos, sendo uma forma eficiente na prevenção e controle da raiva. Este estudo localizou abrigos de $D$. rotundus na região Centro Leste do estado de São Paulo e identificou os tipos de abrigos utilizados (naturais ou artificiais), sua proximidade a corpos de água, composição sexual e população estimada das

\footnotetext{
${ }^{1}$ Universidade Federal de São Carlos. Correspondência: paulomialhe@gmail.com

${ }^{2}$ Universidade Federal de São Carlos, lemoschini@ufscar.br
}

Mialhe PJ, Moschini LE, Trevisan DP. Vampire Bat Desmodus rotundus shelters in the central region of São Paulo state, Brazil. Vet. e Zootec. 2021; v28: 001-009. 
colônias. Foram realizadas buscas por colônias de morcegos hematófagos em abrigos naturais e artificiais durante 2002 a 2004, abrangendo 18 municípios. Após serem localizados, os abrigos foram georreferenciados registrados quanto à natureza do abrigo. (natural ou artificial), utilização (abrigos de machos, maternidades, digestório) e população estimada. Os dados foram incorporados em um SIG, produzindo-se um mapa temático da localização dos abrigos e sua distância dos corpos hídricos locais. Foram encontrados cerca de 1567 indivíduos da espécie D. rotundus distribuídos em 94 abrigos, onde apenas seis abrigos $(6,38 \%)$ eram naturais (grutas). A maioria dos abrigos $(79,78 \%)$ era pouco populoso, com até 15 morcegos, incluindo os abrigos de machos (46 abrigos) e 30 maternidades $(63,82 \%$ das maternidades). Cinco abrigos (5,37\%) possuíam entre 50 e 100 morcegos e apenas dois abrigos $(2,15 \%)$ possuíam uma população superior a 100 morcegos. Seis abrigos $(6,38 \%)$ eram casas habitadas, o que é preocupante para a saúde pública, pois estas podem constituir uma fonte de contaminação perigosa para carnívoros domésticos e humanos. Todos os abrigos estavam a uma distância de até $2 \mathrm{~km}$ de rios ou riachos. $\mathrm{O}$ alto percentual de abrigos artificiais encontrados é consequência da intensificação das alterações antrópicas que proporciona o aumento da oferta de alimento e abrigos a $D$. rotundus, que associado a grande rede de drenagem favorece a dispersão desta espécie de morcego na região. A proximidade dos todos os abrigos de D. rotundus a rede de drenagem corrobora outros estudos no estado de São Paulo, em que as áreas próximas aos principais rios geralmente favorecem a existência de um número maior de abrigos.

Palavras-chave: Morcego-vampiro; abrigos de morcegos; SIG.

\section{ALBERGUES DE MURCIÉLAGOS HEMATOPHAGUS DESMODUS ROTUNDUS EN LA REGIÓN CENTRAL DEL ESTADO DE SÃO PAULO, BRASIL}

\section{RESUMEN}

El murciélago vampiro Desmodus rotundus es el principal transmisor de la rabia en los herbívoros domésticos, lo que provoca pérdidas económicas en el ganado, además de ser un grave problema de salud pública. El uso de Sistemas de Información Geográfica (SIG) permite el monitoreo espacial de los refugios de estos murciélagos, siendo una forma eficiente de prevenir y controlar la rabia. Este estudio localizó refugios de D. rotundus en la región Centro-Este del estado de São Paulo e identificó los tipos de refugios utilizados (naturales o artificiales), su proximidad a cuerpos de agua, composición sexual y población estimada de las colonias. Se realizaron búsquedas de colonias de murciélagos vampiros en refugios naturales y artificiales durante 2002 a 2004, abarcando 18 municipios. Una vez ubicados, se georreferenciaron los refugios y se registró la naturaleza del refugio (natural o artificial), uso (refugios masculinos, maternidades, digestivo) y población estimada. Los datos se incorporaron a un SIG, produciendo un mapa temático de la ubicación de los refugios y su distancia a los cuerpos de agua locales. Se encontraron 1567 individuos de la especie $D$. rotundus distribuidos en 94 refugios, donde solo seis refugios $(6,38 \%)$ eran naturales (grutas). La mayoría de los refugios (79,78\%) estaban escasamente poblados, con hasta 15 murciélagos, incluidos los refugios para machos (46 refugios) y 30 criaderos $(63,82 \%$ de los criaderos). Cinco refugios $(5,37 \%)$ tenían entre 50 y 100 murciélagos y solo dos refugios $(2,15 \%)$ tenían una población superior a 100 murciélagos. Seis albergues $(6,38 \%)$ eran viviendas habitadas, lo que es una preocupación para la salud pública, ya que pueden constituir una peligrosa fuente de contaminación para carnívoros domésticos y humanos. Todos los refugios estaban a una distancia de hasta $2 \mathrm{~km}$ de ríos o arroyos. El alto porcentaje de refugios artificiales encontrados es consecuencia de la intensificación de alteraciones antropogénicas que

Mialhe PJ, Moschini LE, Trevisan DP. Vampire Bat Desmodus rotundus shelters in the central region of São Paulo state, Brazil. Vet. e Zootec. 2021; v28: 001-009. 
proporcionan un aumento en la oferta de alimento y refugio para $D$. rotundus, lo que asociado a una gran red de drenaje favorece la dispersión de esta especie de murciélago en la región. La proximidad de todos los refugios de $D$. rotundus a la red de drenaje corrobora otros estudios en el estado de São Paulo, en los que las áreas cercanas a los principales ríos favorecen en general la existencia de un mayor número de refugios.

Palabras clave: murciélago vampiro; refugios para murciélagos; SIG.

\section{INTRODUCTION}

Rabies is considered an anthropozoonosis and a progressive viral encephalomyelitis, with near $100 \%$ lethality, which affects different species of terrestrial mammals, bats, and even man. The rabies virus is a bullet-shaped enveloped RNA virus, order Mononegavirales, family Rhabdoviridae, genus Lyssavirus. It is transmitted between susceptible directly through bites, scratches, or contamination of mucous membranes with saliva, without the participation of arthropod vectors $(1,2)$.

Rabies is a serious public health problem and causes major economic damage to livestock. It has four epidemiological cycles: air (involving bats), rural (involving farm animals), urban (involving dogs and cats and the terrestrial wild (involving marmosets, bush dogs, and foxes, among other animals) $(1,3)$. Risk factors for rabies occurrence include low vaccination coverage, suspected or confirmed rabies cases, environmental changes, and rabies virus or disease in vampire bats $(4,5)$.

Considerable changes regarding the disease transmitter can be observed. The analyzes of the cycle's participation in the transmission to humans, from the '80s, reveals a clear decrease of the urban cycle involvement and increase participation of the air cycle in more recent years (6).

In the Brazilian context, the Ministry of Health and the State and Municipal Health Secretariats care for urban rabies control, the herbivore rabies control is controlled by the federal level by the Ministry of Agriculture, Livestock and Supply (MAPA in Brazil), and by the State Animal Defense in the federation units, through the actions of the National Herbivorous Rabies Control Program (PNCRH). The goal is to reduce the prevalence of the disease in the domestic herbivore population, and the action strategy is based on herbivores' vaccination and control of vampire bats (Desmodus rotundus), using vampiric paste (anticoagulant warfarina), which bats ingest and provoke its death $(2,6)$.

The control methods used are selective only for D. rotundus bats that are attacking domestic herbivores, so as not to affect other bat species and the ecosystem and may be indirect and direct. Indirect selective control is based on the habit of D. rotundus returning the same wound made in the prey to feed for consecutive days. The farmer applies the vampiric paste around the wound of the attacked animal, and when the bat returns to feed on the same wound, licking it takes in the vampiric paste, causing its death $(7,8)$.

The method of direct selective control is based on the behavior of D. rotundus in the colonies, which group into compact groups, perform grooming, and share food with other individuals in the group. Bats are caught near food sources or in their shelters with the aid of hammocks, and a paste containing an anticoagulant ( $2 \%$ warfarin, also called vampiricide paste) is applied to its back and then released. These bats return to their colony where the other members ingest the anticoagulant at the time of mutual cleansing. The capture should only be performed by the official services, by technicians duly trained and equipped for the correct execution of this activity, and only in the properties where the coefficients are more expressive (above 5\%) (3).

Mialhe PJ, Moschini LE, Trevisan DP. Vampire Bat Desmodus rotundus shelters in the central region of São Paulo state, Brazil. Vet. e Zootec. 2021; v28: 001-009. 
There are different types of shelters: daytime or permanent (where they stay most of the time) the nocturnal or digestive (where they remain the time necessary for digestion after feeding to return to the permanent shelter) and the maternity (which gather females, their pups and dominant males). All shelters are indoors protecting bats from environmental weather such as temperature, humidity, light, and rainfall (3).

In regions of the New World, where there are intense livestock activities, D. rotundus colonies have 50 to 100 individuals, but their colonies may be larger especially in areas where they are sporadically controlled. The fundamental social unit of this species is the harem formation, in which a group of eight to 12 females and their young are protected by a dominant male. Young males, at the age of one, are expelled from the original group, while females are recruited as future mates. Young expelled from the colony can stay in the same shelter, in nearby shelters, or even move to other areas, joining other males forming single male clusters (8).

The changes that occur in natural landscapes, caused mainly by man, have considerably affected the population of Chiroptera and triggering a series of ecological consequences that affect man, such as the resurgence of Rabies. The increase in the food supply, represented by the significant growth of herds; disordered occupation, characterized by environmental macro modifications, such as deforestation, road construction, and hydroelectric dams, which altered the environment in which bats live, forcing them to look for new areas and other sources of food. The increase in the supply of artificial shelters represented by buildings, such as tunnels, cisterns, abandoned or inhabited houses, manholes, deactivated coal furnaces, among others, have contributed to the spread of rabies $(8,9)$.

Spatial analysis is a widely used tool in ecological studies, which allows mapping and demonstrating locations of risk for disease development and evidence of its association with various factors, represented living organisms and physical environment $(10,11)$. Geographic Information Systems (GIS) have been used to improve the control and monitoring mechanism of outbreaks and shelters of the main rabies transmitters, being an efficient way to prevent and act on eventual outbreaks of the disease $(11,12)$.

This study aimed to locate D. rotundus shelters in the Center East region of São Paulo state and identify the types of shelters used (natural or artificial), proximity to water, sexual composition, and estimated population of the colonies.

\section{MATERIALS AND METHODS}

The research was carried out during 2002 - 2004 in the Center East Region of São Paulo state, covering 18 municipalities: São Carlos, Analândia, Araraquara, Descalvado, Dobrada, Tabatinga, Américo Brasiliense, Cândido Rodrigues, Monte Alto, Pirangi, Taquaritinga, Matão, Santa Lucia, Ibaté, Ribeirão Bonito, Trabiju, Dourado e Boa Esperança. The region has altitudes ranging from 412 to $112 \mathrm{~m}$, with areas of pasture areas, perennial and semiperennial agriculture, where it is practiced agriculture, with a high number of rural constructions.

Searches were performed for vampire-bat colonies in natural and artificial refuges. After being located, the shelters were georeferenced using a Garmin ${ }^{\circledR}$-Etrex model GPS receiver. It was recorded the type of the shelter (natural or artificial), utilization (male shelters, maternity wards, digestion), and population. The estimate of the bat population in the shelters was made visually, by calculating the number of bats in one square meter and then multiplying by the total area occupied by them, besides the number of fresh feces existing in the (13). place

For the elaboration of the thematic map with the shelters' location and their distance from the water, the data were grouped in a Geographic Information System (GIS). It was used

Mialhe PJ, Moschini LE, Trevisan DP. Vampire Bat Desmodus rotundus shelters in the central region of São Paulo state, Brazil. Vet. e Zootec. 2021; v28: 001-009. 
the ArcGIS 10.2 software and topographic charts in 1: 50.000, available on the digital database of the Brazilian Institute of Geography and Statistics (IBGE).

\section{RESULTS}

We found 1567 individuals of the species D. rotundus distributed in 94 shelters in 18 municipalities. The cities with the largest number of shelters were São Carlos (32 shelters) and Ribeirão Bonito (14 shelters). Four other cities (Américo Brasiliense, Araraquara, Descalvado, and Dourado) had between five and ten shelters, and the rest of the municipalities had only one to four shelters.

Only six shelters $(6.38 \%)$ were natural (caves). From the 88 artificial shelters remaining: $29(30.85 \%)$ were abandoned houses, $24(25.53 \%)$ tunnels, $17(18.08 \%)$ storage areas, six $(6.38 \%)$ inhabited houses, and $12(12.76 \%)$ shelters distributed in various rural buildings, such as corral (1), abandoned water tanks (4), mill (1), wells (2), basements (3) and manhole (1). The map with the shelter's location and the drainage network is illustrated in Figure 1.

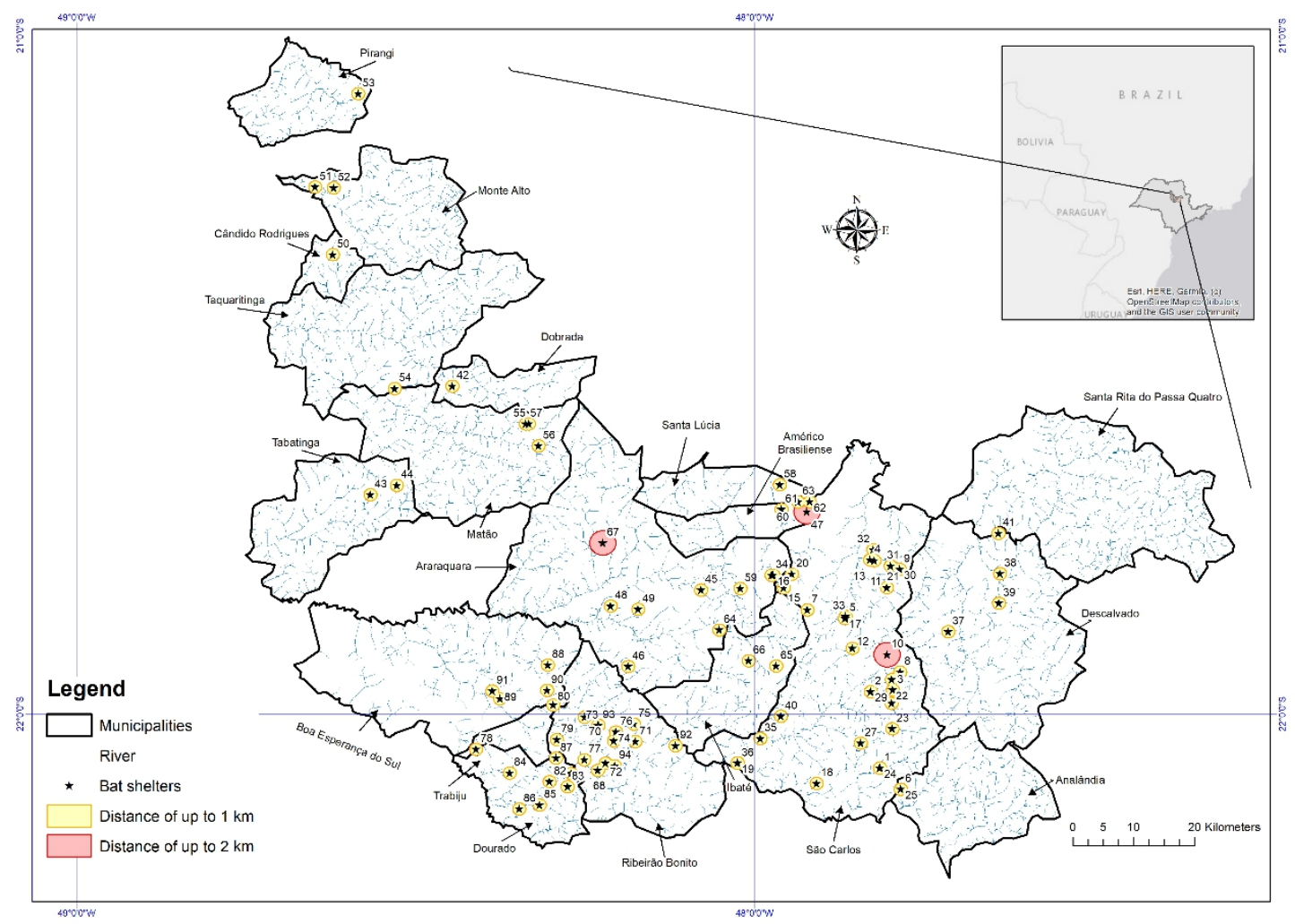

Figure 1 - Vampire bat shelters and proximity to water

Regarding the use of shelters, 47 maternity shelters, 46 single male shelters, and an uninhabited digestive shelter were found, evidenced by the presence of fresh pasty feces of $D$. rotundus.Regarding population size in the shelters, 75 shelters $(79.78 \%)$ had a small population with up to 15 bats, 10 shelters $(10.63 \%)$ had a population between 16 to 50 bats, five shelters $(5.31 \%)$ had a population between 51 and 100 bats, one $(1.06 \%)$ shelter had a population of 124 bats, one shelter $(1.06 \%)$ had a population of over 300 bats and one uninhabited shelter (1.06\%), being used as digestive.

Mialhe PJ, Moschini LE, Trevisan DP. Vampire Bat Desmodus rotundus shelters in the central region of São Paulo state, Brazil. Vet. e Zootec. 2021; v28: 001-009. 
All shelters were located near a river or stream, and 92 shelters $(97.87 \%)$ were located at a distance of up to $1 \mathrm{~km}$ and only two $(2.12 \%)$ were located at a distance of up to $2 \mathrm{~km}$ from these.

\section{DISCUSSION}

In the present study, the majority (93.63\%) of D. rotundus shelters found were artificial, surpassing the percentage of artificial shelters found in São Paulo state (86.14\%) (12). The largest percentage of shelters were abandoned houses $(30.85 \%)$, close to that found in cities in the region of the Paraíba Valley - SP (28.57\%) (8) and lower than other studies in the state of São Paulo (46.9\%) (14).

The proportion of maternity shelters and male shelters was fairly equitable: 46 male bat shelters and 48 maternity shelters. Of the six natural shelters found, four were single male colonies $(66.67 \%)$ and two (33.33) maternity wards, which also differs from other studies in São Paulo state $(8,15)$ where all-natural shelters were maternity wards. Although the number of single males represented only $10.8 \%$ of the population, they occupied $48.93 \%$ of the available shelters. Studies in São Paulo state show the exclusivity or predominance of males in more than $60 \%$ of the studied groups. Lack of mating females is likely to increase the displacement of single males to other shelters, which may explain the high occupation of shelters by small populations of single males (8).

This greater dispersion of male bats plays an important role in control activities. Males dispute territories and practically do not groom, unlike females, where grooming and food sharing (regurgitation) substantially increase contact between colony members, causing dispersion of the vampiric paste and consequent efficiency of direct selective control. For male control, the ideal would be to combine indirect and direct methods to effectively reduce their population $(7,8)$.

Most shelters $(79.78 \%)$ were sparsely populated with up to 15 bats, including all-male shelters (46 shelters) and 30 maternity wards (63.82\% of maternity wards). Five shelters (5.37\%) had between 50 and 100 bats and only two shelters $(2.15 \%)$ had a population of over 100 bats. Colonies with more than 52 individuals are considered as old and stable and are considered as older and stabilized colonies (14) and colonies larger than 100 individuals occur in regions where population control is not performed (15).

Thus, most $D$. rotundus shelters in the region had probably been recently colonized, favored by many artificial shelters available in the region and the high adaptive capacity of this bat to this type of shelter. Only $7.52 \%$ of the shelters had a population of over $50 \mathrm{D}$. rotundus, all maternity, which were probably sources of bat dispersal to colonize new shelters. Although maternity rates are slightly higher than those found in other studies in São Paulo state, the low population found in most $D$. rotundus shelters indicates that population control of this species is under control in the region.

The location of colonies of D. rotundus in non-abandoned houses, where people and animals move, is a matter of public health concern, as they can be a source of dangerous contamination. The predation of bats by domestic carnivores, such as dogs and cats, constitutes a favorable relationship for the transmission of the rabies virus (16).

Analysis of rabies virus samples isolated in Brazil (17) detected the antigenic variant of D. rotundus (AgV3) in positive feline, dog, and human samples, which is of concern, as once infected with chiropteran rabies variants, these animals can transmit the disease to the man called the secondary cycle, where the bat transmits the rabies virus to a feline, which in turn transmits to the man (16).

Mialhe PJ, Moschini LE, Trevisan DP. Vampire Bat Desmodus rotundus shelters in the central region of São Paulo state, Brazil. Vet. e Zootec. 2021; v28: 001-009. 
All shelters were within a distance of up to $2 \mathrm{~km}$ from rivers and streams, corroborating other studies in São Paulo state $(13,14)$ where areas near major rivers generally favor the existence of more shelters.

\section{CONCLUSIONS}

The high percentage of artificial shelters found is a consequence of the anthropic intensification that causes an increase in the supply of this shelter type to D. rotundus, which is associated with a large drainage network and food provided by local livestock, favors the dispersal of this species in the region.

D.rotundus shelters must be monitored and data shared between animal and public health agencies. Especially in cases where bats colonize house that is inhabited or where people or animals are in transit due to the infection risk from rabies virus to domestic carnivores and people via the secondary cycle. Vaccination of domestic carnivores should be up to date and health education activities should be performed.

\section{REFERENCES}

1. Moutinho FFB, Nascimento ER, Paixão RL. Raiva no Estado do Rio de Janeiro, Brasil: análise das ações de vigilância e controle no âmbito municipal. Cienc Saude Colet [Internet]. 2015 [cited 2018 Jun 24]; 20(2):577-86. Available from: https://www.researchgate.net/publication/273508924_Raiva_no_Estado_do_Rio_de_Janeir o_Brasil_Analise_das_acoes_de_vigilancia_e_controle_no_ambito_municipal

2. Pisa ACC. Efeito do controle de morcegos Desmodus rotundus na ocorrência de focos de raiva no estado do Espírito Santo [dissertação] [Internet]. Pirassununga (SP): Faculdade de Medicina Veterinária e Zootecnia, Universidade de São Paulo; 2015 [cited 2018 Jun 24]. Available from: https://www.teses.usp.br/teses/disponiveis/10/10134/tde-25082015102004/pt-br.ph

3. Brasil. Ministério da Agricultura, Pecuária e Abastecimento. Controle da raiva dos herbívoros: manual técnico [Internet]. Brasília: Mapa/ACS; 2009 [cited 2018 Jun 24]. p. 43-56. Available from: https://www.gov.br/agricultura/pt-br/assuntos/sanidade-animal-evegetal/saude-animal/programas-de-saude-animal/raiva-dos-herbivoros-eeeb/MANUAL_RAIVAHERBVOROS2009.pdf

4. Horta MA, Oliveira DG, Miranda EMC, Guterres A. Serological survey of rabies virus infection among bats in Brazil. Virus Rev Res [Internet]. 2018 [cited 2018 Jun 24];23(1):1$10 . \quad$ Available from: https://www.researchgate.net/publication/322997867_Serological_Survey_of_Rabies_Viru s_Infection_among_Bats_in_Brazil

5. Marinho KC. Epidemiologia e distribuição espaço-temporal da raiva no Espirito Santo, entre os anos de 1994 e 2013 [dissertação] [Internet]. Vitoria: Centro de Ciências da Saúde, Universidade Federal do Espírito Santo; 2015 [cited 2018 Jun 24]. Available from: https://repositorio.ufes.br/bitstream/10/5561/1/tese_8812_Disserta\%c3\%a7\%c3\%a3o\%20 Karina\%20Marinho.pdf 
6. Brasil. Ministério da Agricultura, Pecuária e Abastecimento - MAPA. Instrução Normativa $\mathrm{n}^{\mathrm{o}}$ 5, de $1^{\mathrm{o}}$ de Março de 2002 [Internet]. Brasília: MAPA; 2002 [cited 2018 Jun 24]. Available from: https://www.agricultura.rs.gov.br/upload/arquivos/201803/27113625pncrh-in-5-2002.pdf

7. Puga LCHP. Modelagem espacial da ocorrência de mordeduras de morcegos hematófagos na Zona da Mata de Minas Gerais [tese] [Internet]. Viçosa (MG): Departamento de Medicina Veterinária, Universidade Federal de Viçosa; 2015 [cited 2018 Jun 24]. Available

from:

https://www.locus.ufv.br/bitstream/123456789/6746/1/texto\%20completo.pdf

8. Ferrari JJF. Morcego hematófago comum Desmodus rotundus no Vale do Paraíba, Estado de São Paulo: abrigos diurnos, agrupamentos, lesões corporais e sorologia antirábica [tese] [Internet]. São Paulo: Faculdade de Saúde Publica, Universidade de São Paulo; 2015 [cited 2018 Jun 24]. Available from: https://www.teses.usp.br/teses/disponiveis/6/6132/tde03082015-113130/publico/JoaoJoseDeFreitasFerrariREVISADA.pdf

9. Mialhe PJ, Moschini LE. Controle populacional do morcego hematófago Desmodus rotundus e redução de ataques a herbívoros domésticos no Município de São Pedro, São Paulo, Brasil. Fronteiras J Soc Technol Environ Sci [Internet]. 2016 [cited 2018 Jun 24];5(3):238-51. Available from: http://periodicos.unievangelica.edu.br/index.php/fronteiras/article/view/2052/1838

10. Marinho KM. Epidemiologia e distribuição espaço-temporal da raiva no Espírito Santo, entre os anos de 1994 e 2013 [dissertação] [Internet]. Vitoria: Centro de Ciências da Saúde, Universidade Federal do Espírito Santo; 2015 [cited 2018 Jun 24]. Available from: https://repositorio.ufes.br/bitstream/10/5561/1/tese_8812_Disserta\%c3\%a7\%c3\%a3o\%20 Karina\%20Marinho.pdf

11. Leite ACCP. Caracterização espacial e identificação dos pontos de abrigos de quirópteros e sua relação com os casos de raiva no semiárido paraibano, Brasil. [dissertação] [Internet]. Campus de Patos (PB): Centro de Saúde e Tecnologia Rural, Universidade Federal de Campina Grande; 2017 [cited 2018 Jun 24]. Available from: http://dspace.sti.ufcg.edu.br:8080/jspui/handle/riufcg/755

12. Coordenadoria de Defesa Agropecuária do Estado de São Paulo. São Paulo tem 4,6 mil abrigos de morcegos hematófagos cadastrados [Internet]. São Paulo; 2016 [cited 2018 Jun 24]. Available from: https://www.defesa.agricultura.sp.gov.br/noticias/2016/saopaulo-tem-46-mil-abrigos-de-morcegos-hematofagos-cadastrados, $975 . \mathrm{html}$

13. Mialhe PJ. Characterization of Desmodus rotundus (E. Geoffroy, 1810) (Chiroptera, Phyllostomidae) shelters in the Municipality of São Pedro- SP. Braz J Biol [Internet]. 2013 [cited 2018 Jun 24];73(3):521-6. Available from: https://www.scielo.br/j/bjb/a/YkVpCDRhdD5wt4dLwWmrZFn/?lang=en

14. Taddei VA, Gonçalves CA, Pedro WA, Tadei WJ, Kotait I, Arieta C. Distribuição do morcego vampiro Desmodus rotundus no Estado de São Paulo e a raiva dos animais domésticos. Campinas: CATI; 1991. (Impresso Especial da CATI).

Mialhe PJ, Moschini LE, Trevisan DP. Vampire Bat Desmodus rotundus shelters in the central region of São Paulo state, Brazil. Vet. e Zootec. 2021; v28: 001-009. 
15. Gomes MN, Uieda W. Abrigos diurnos, composição de colônias, dimorfismo sexual e reprodução do morcego hematófago Desmodus rotundus (E. Geoffroy) (Chiroptera, Phyllostomidae) no Estado de São Paulo, Brasil. Rev Bras Zool [Internet]. 2004 [cited 2018 Jun 24];21(3):629-38. Available from: https://www.scielo.br/j/rbzool/a/yfPJ6Pv5Q5cwHRVdbbJf5Dd/?lang=pt

16. Moraes JEC, Zanata AF, Thomé CM, Moreira DB, Presotto D, et al. Raiva felina no município de Jaguariúna, Estado de São Paulo, em 2010. BEPA Bol Epidemiol Paul [Internet]. 2011 [cited 2018 Jun 24];8(96):4-10. Available from: http://periodicos.ses.sp.bvs.br/pdf/bepa/v8n96/v8n96a01.pdf

17. Favoretto SR, Carrieri ML, Cunha EM, Aguiar EA, Silva LH, Sodre MM, et al. Antigenic typing of Brazilian rabies virus samples isolated from animals and humans, 1989-2000. Rev Inst Med Trop São Paulo [Internet]. 2002 [cited 2018 Jun 24];44(2):91-5. Available from: https://www.scielo.br/j/rimtsp/a/S5xSxDLcMyfZbPD7Vw98Jyv/?lang=en

Recebido em: 14/06/2021 Aceito em: 31/08/2021 